\title{
Interjú iskolai szociális munkásokkal
}

Az Iskolai Szociális Munkások Egyesülete (ISME) honlapját naponta 100-150 látogató keresi fel, és közösségi oldalának is 670 követője van, akik jelentős része valószínüleg szakmabeli. A 2017/18-as tanév végén az iskolai szociális segítőktől kérdeztünk az előző egy év eredményeiről. Az alábbiakban két, az iskolai szociális munkában több évet dolgozót szólaltatunk meg. Nagy Tímea szociális munkás és Nyíri Noémi szociálpedagógus egykori iskolai szociális munkások mondták el véleményüket, tapasztalataikat.

ISME: Mióta és milyen kapcsolatod van az iskolai szociális munkával? Mennyi idöt dolgoztál benne, milyen típusú iskolában, milyen modellben?

N. T.: Közel tíz éve szakmai gyakorlat keretében ismerkedtem meg a területtel, az iskolai szociális munka pécsi modelljének keretei között. Ezt követően bekapcsolódtam az Iskolai Szociális Munkások Egyesületének (ISME) tevékenységébe, egyúttal a területről zajló folyamatos és egyre nagyobb érdeklődésnek örvendő szakmai párbeszédbe. 2010-től három éven át belső modellben dolgoztam a Gandhi Közalapítványi Gimnázium és Kollégium iskolai szociális munkásaként. Az itt töltött évek alatt az egyesületen keresztül folyamatosan kapcsolatban voltam más iskolában dolgozó szociális munkásokkal is. 2015-ben közremüködtem annak a munkaanyagnak a létrejöttében, amelyet az EMMI Szociális és Gyermekjóléti Szolgáltatások Főosztálya megbízásából az Iskolai Szociális Munkások Egyesülete készített el, az iskolai szociális munka bevezetésének előkészítéséhez.

Ny. N.: Két teljes tanévet dolgoztam iskolai szociális munkásként, egy budapesti vendéglátóipari középiskolában Köbányán. A pécsi INDIT Közalapítvány egy főváros által kiírt pályázat keretében foglalkoztatott, másik 4 kollégával együtt.

ISME: Mit gondolsz a bevezetendő óvodai-iskolai szociális segítő szolgáltatásról?

N. T.: A szakma részéről az elmúlt években számos erőfeszítés történt annak érdekében, hogy megfelelö keretek jöjjenek létre a szociális szakemberek iskolában történő alkalmazására. A most bevezetendő szolgáltatást részben örömmel fogadhatjuk, hiszen ez azt jelenti, hogy a döntéshozók is elismerték, az iskoláknak szüksége van az ilyen jellegü támogatásra. Másfelöl azonban aggodalomra ad okot, hogy a szolgáltatást olyan feltételek mellett lehet majd megszervezni, ami rendkívül beszükíti a szakemberek mozgásterét, ilyen keretek között aligha lesznek képesek kiaknázni mindazt a lehetőséget, mely az iskolai szociális munkában rejlik.

Amikor döntés született arról, hogy 1000 fö köznevelési intézményben nyilvántartott gyerekre nézve egy fő fő́llású segítő alkalmazására lesz lehetőség, nem vették figyelembe, hogy ez a gyakorlatban azt jelenti, hogy az érintett szakember a legjobb esetben is heti 1-1,5 napon lesz elérhető egy-egy iskolában. Sajnos ez még mindig nem teszi lehetővé, hogy a segítő ténylegesen bekapcsolódjon a közösség életébe, jelen legyen az aktuális krízishelyzeteknél, vagy elegendő időt fordítson a felkészülésre, konzultációkra, csoportfoglalkozásokra, netán a pozitív iskolai légkör fejlesztésére. 
Mindemellett számos megválaszolatlan kérdéssel kell még szembenéznünk. Lesz-e elég szakember a feladat ellátására, milyen támogatást kapnak a benne dolgozók a szolgáltatás elindításához, a szakmai felkészüléshez? A koncepcióban az óvodai-iskolai szociális segítésszolgáltatás csak a gyermekjóléti szolgálat keretében kerülhet megszervezésre. Mi lesz azokkal az iskolákkal, esetleg más külső szervezetekkel, amelyek maguk szeretnének foglalkoztatni szociális munkást?

NY. N.: Több évvel ezelött még én is részt vettem egy, a minisztérium által összehívott munkacsoportban, amelyben több terület szakemberei együtt gondolták végig a szükségleteket és területi, ellátási specifikumokat. Akkor ott nagyon sok szempont figyelembevételével, maximális szakmaisággal készült egy szakértői anyag, majd pár évvel később egy újabb. Ezekben az anyagokban a szükségletekhez igazított ellátási/müködtetési formák kerültek leírásra. A mostani koncepció (jelen ismeretem szerint) figyelmen kívül hagyott nagyon sok mindent, amit ezekben az anyagokban leírtak, például, hogy a hatékony munkavégzés fontos feltétele a hét 5 napján való állandó jelenlét vagy az, hogy az iskolai populáció sajátosságai alapján kellene meghatározni a szociális munkások számát. Természetesen én is üdvözlöm azt a kezdeményezést, hogy lesznek iskolai és óvodai szociális munkások. Azonban erősen kérdéses a végezhető munka hatékonysága abban az esetben, ha a megszabott létszámnorma alapján egy segítő akár 3-4-5, vagy akár több iskoláért is kell, hogy feleljen. Félő az is, hogy nem biztosítanak majd megfelelő feltételeket minden iskolában. Saját tapasztalataimat figyelembe véve a hatékony és diákbarát munka fontos feltétele egy saját iroda, ahol a segítö folyamatosan elérhető és nyugodt környezetben folytatható konzultációs munka.

\section{ISME: Te milyen keretek között dolgoznál legszívesebben (minimum/optimális)?}

N. T.: Optimálisnak azt tartanám, ha egy fóállású szakember egy iskolát látna el. A szociális szakember munkarendje igazodna a tanév rendjéhez, illetve a pedagógusok, a pedagógiai munkát közvetlenül segítők, például az iskolapszichológusok munkarendjéhez. Fontosnak tartom azt is, hogy a szakemberek tevékenységüket külső szupervízió, rendszeres esetmegbeszélők, folyamatos továbbképzési lehetőség mellett végezhessék. A minimális tárgyi feltételek teljesülése pedig elengedhetetlen a megfelelő munkavégzéshez. Ideértendő egy konzultációra alkalmas helyiség, iroda, saját számítógép, telefon és a különbözö foglalkozásokhoz szükséges eszközök.

NY. N.: Számomra az INDIT Közalapítvány által kialakított módszertani keret megfelelő volt: teamben dolgozni, heti esetmegbeszélők tartása, koordinátor, aki vezette a teamet, szakmai vezetés és tanácsadás rendelkezésre állása, rendszeres szupervízió és egy intézményi fönök, aki, ha kellett jött és leült az iskolai igazgatóval tárgyalni. Ezentúl olyan infrastrukturális feltételek, mint saját iroda, laptop, barátságos környezet megteremtésének anyagi feltételei és maximális szakmai háttértámogatás.

\section{ISME: A kezdeti időszakban milyen tanáccsal látnád el a gyakorlatban dolgozókat?}

N. T.: Amennyire lehet, szánjanak időt a szolgáltatás előkészítésére: ismerjék meg az intézményt. A vezetőséggel közösen alakítsák ki az iskola szükségleteinek megfelelö munkatervet, ismertessék a szolgáltatás lehetőségeit, tisztázzák a kompetenciahatárokat. Alakítsanak ki együttmüködést az iskolában dolgozó más segítőkkel. Ismerjék meg az iskola 
szereplőit, teremtsenek bizalmi kapcsolatot a diákokkal, pedagógusokkal, szülőkkel. A lehetőségekhez mérten vegyenek részt a közösség életében, iskolai rendezvényeken, kirándulásokon. Lépjenek kapcsolatba olyan külső szervezetekkel, amelyek segíthetik a munkájukat.

NY. N.: Pályakezdő ne akarjon iskolai szociális munkás lenni. Türelem és kitartás, legalább 1 év, mire kezd a befektetett munka beérni és elkezdik érteni és használni a szolgáltatást. Az iskolán belüli megfelelő kulcsszemélyek megtalálása, legalább 1 fö a vezetőségből és a pedagógus munkacsoport vezetője. Törekedni kell iskolán belüli segítő team kialakítására, például a védőnővel, az ifjúságvédelmi felelőssel vagy bárkivel, aki a gyerekek lelkével kicsit is foglalkozik. Bekapcsolódni minden programba és részt venni mindenben, amiben csak lehet.

ISME: Megköszönve a válaszokat, bízunk abban, hogy nemcsak az iskolai szociális munkások, hanem az iskolaigazgatók és más iskolapolgárok számára is segítségül szolgálnak az elhangzott információk. 